Species Diversity, 2004, 9, 151-164

\title{
The Agathidinae (Insecta: Hymenoptera: Braconidae) of Sakhalin and the Kuril Islands
}

\author{
Michael J. Sharkey ${ }^{1}$ and Daniel J. Bennett ${ }^{2}$ \\ ${ }^{1}$ Department of Entomology, College of Agriculture, S-277 Agricultural Sciences Building \\ North, University of Kentucky, Lexington, Kentucky 40546-0091, U.S.A. \\ ${ }^{2}$ School of Aquatic and Fishery Sciences, University of Washington, Seattle, \\ Washington 98195, U.S.A. \\ Current Address: Division of Entomology, Natural History Museum, and Department of \\ Ecology and Evolutionary Biology, Snow Hall, 1460 Jayhawk Blvd, \\ University of Kansas, Lawrence, Kansas 66045-7523, U.S.A. \\ E-mail: danben@ku.edu
}

(Received 25 January 2003; Accepted 25 December 2003)

\begin{abstract}
Recent collecting on Sakhalin and the Kuril Islands, during joint U.S., Russian, and Japanese surveys known as the International Kuril and Sakhalin Island Projects, has resulted in range extensions for 10 species in the braconid subfamily Agathidinae and 17 new taxon records for islands in the Kuril chain, Sakhalin, and Moneron. In addition to a check list of the 19 species of Agathidinae presently known to occur on Sakhalin and the Kuril Islands, a generic key and updated keys to the species of Agathis Latreille, 1804, Bassus Fabricius, 1804, and Coccygidium Saussure, 1892 are provided for the region at large (i.e., Japan and the Russian Far East). Of the Agathidinae occurring on Sakhalin and the Kuril Islands, most are widespread throughout the Russian Far East and Japan. In the Kurils, species are largely restricted to the southern portion of the archipelago.

Key Words: Hymenoptera, Braconidae, Agathidinae, Japan, Russian Far East, Kuril Islands, identification keys.
\end{abstract}

\section{Introduction}

The primary objective of this article is to facilitate the identification of the species of Agathidinae found in the temperate regions of the eastern Palearctic and to incorporate new distribution data discovered during the biotic surveys of the International Kuril and Sakhalin Islands Projects (IKIP and ISIP), years 1995-2001. Sharkey (1996) presented a key to the Japanese species of Agathidinae and also (Sharkey 1998) a key to the Agathidinae of the Russian Far East. The latter publication is in Russian and may be inaccessible to some potential users. The present treatise is the first to include all species of Agathis Latreille, 1804, Bassus Fabricius, 1804, and Coccygidium Saussure, 1892 known from the Russian Far East and Japan (Fig. 1) and will be more useful than either of the former publications since species only recorded in one area may prove to be present in the other.

The Agathidinae comprise almost 1,000 described species and several times that number of undescribed species worldwide. All known agathidines are koino- 


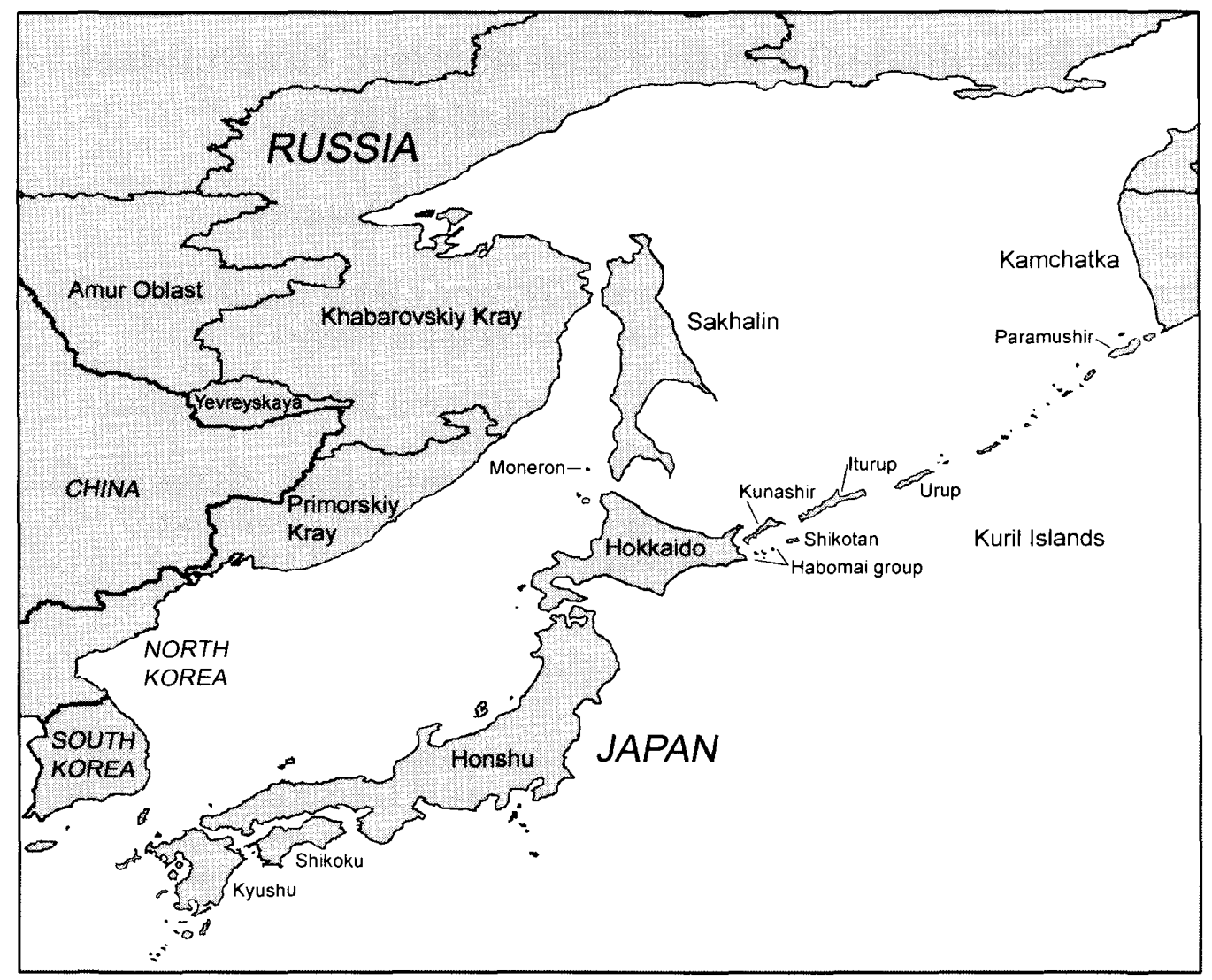

Fig. 1. Map of Japan and the Russian Far East.

biont endoparasitoids of larval Lepidoptera. Most host larvae are leaf rollers or stem borers, though about $20 \%$ of the hosts are free-living foragers and many of these are crepuscular or nocturnal. Usually eggs are laid in the first or second instar of the host larvae except for members of the Cremnoptini and Disophrini, which may attack later instars as well. The adult parasitoid emerges after the final instar of the host has spun its cocoon (Nickels et al. 1950; Dondale 1954; Odebiyi and Oatman 1972, 1977). For a thorough introduction to the subfamily, readers should consult Sharkey (1996).

Members of the Agathidinae that occur in the eastern Palearctic may be distinguished from all other braconids by the following set of characters: forewing vein $\mathrm{M}+\mathrm{CU}$ not tubular in basal $3 / 4$ or more; second submarginal cell of forewing small, or rarely absent, as in Aneurobracon Brues, 1930; occipital carina not present; vein 2cu-a of forewing absent; RS vein of forewing meeting wing margin near stigma, thus forming a rather narrow marginal cell (except in Aneurobracon, in which vein $\mathrm{RS}$ is absent).

Previous publications on the Agathidinae of the eastern Palearctic include the following. Tobias (1976) revised the species of Bassus (as Microdus von Esenbeck, 1814) of the Russian Far East. Belokobylskij (1989) revised the Palearctic species of Braunsia Watanabe, 1937 and the species of Coccygidium of the Russian Far East (Belokobylskij 1993). Telenga (1955) provided a key to the species of Agathidinae of the USSR, including many species that occur in the Russian Far East. Sharkey 
(1996) revised the species of Agathidinae of Japan and included some species occurring in the Russian Far East. Chou and Sharkey (1989) revised the Agathidinae of Taiwan, and Sharkey (1998) revised and keyed the species of the Russian Far East. Simbolotti and van Achterberg (1999) revised the western Palearctic species of Agathis and made comments on those found in the eastern Palearctic.

\section{Materials and Methods}

Morphological terminology follows Sharkey and Wharton (1997). The percentiles $(\%)$ indicated in the keys represent the frequency with which the user can expect to observe the character state given a specimen that keys to that side of the couplet. We weighted the common species to arrive at these figures. Users should refer to Sharkey (1996) for keys to the species of Braunsia, Cremnops Foerster, 1862, Euagathis Szépligeti, 1900, and Earinus Wesmael, 1837 and for additional illustrations.

Abbreviated locality data for specimens representing taxa newly recorded for islands [labelled in the text as "new island record(s)"] are summarized in the appendix. Detailed locality data and habitat descriptions are accessible via online databases posted at $\langle\mathrm{http}: / /$ okhotskia.ws $\rangle$. All specimens represented by the field numbers below are deposited in the insect collection at the University of Kentucky, Lexington, Kentucky, USA.

In the check list that follows, nomenclatorial histories are included where such are not readily available in Sharkey (1996) or Simbolotti and van Achterberg (1999).

\section{Taxonomy}

\section{Key to Russian Far East and Japanese Genera of Agathidinae}

1. Claws of fore and middle legs simple, with or without basal lobe (Figs 15, 18-20)

- Claws of fore and middle legs bifid (cleft) (Figs 16, 17) ............................... 7

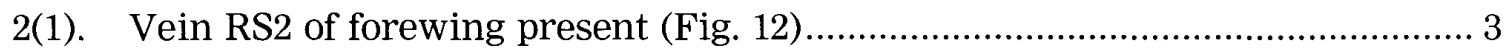

- $\quad$ Vein RS2 of forewing absent (Figs 10, 11, 13, 14) ........................................ 4

3(2). Notaulus and sternaulus present ...................................................... Braunsia

- Notaulus and sternaulus absent....

Laccagathis Watanabe, 1934 [one Palearctic species, Laccagathis japonica Watanabe, 1934, known from Japan (Honshu, Kyushu)]

4(2). Vein RS $+M$ of forewing present (Fig. 10) ........................................... Earinus

- $\quad$ Vein RS $+\mathrm{M}$ of forewing absent (Fig. 11) .................................................. 5

5(4). Venation of forewing greatly reduced, absent distad of stigma except for crossvein r (Fig. 13) ................................................................... Aneurobracon [one Palearctic species, Aneurobracon philippinensis (Muesebeck, 1932), known from Japan (Honshu, Kyushu), the Philippines, and Taiwan] - Venation of forewing more complete, at least RS also present distad of stigma (Figs 10-12, 14). 

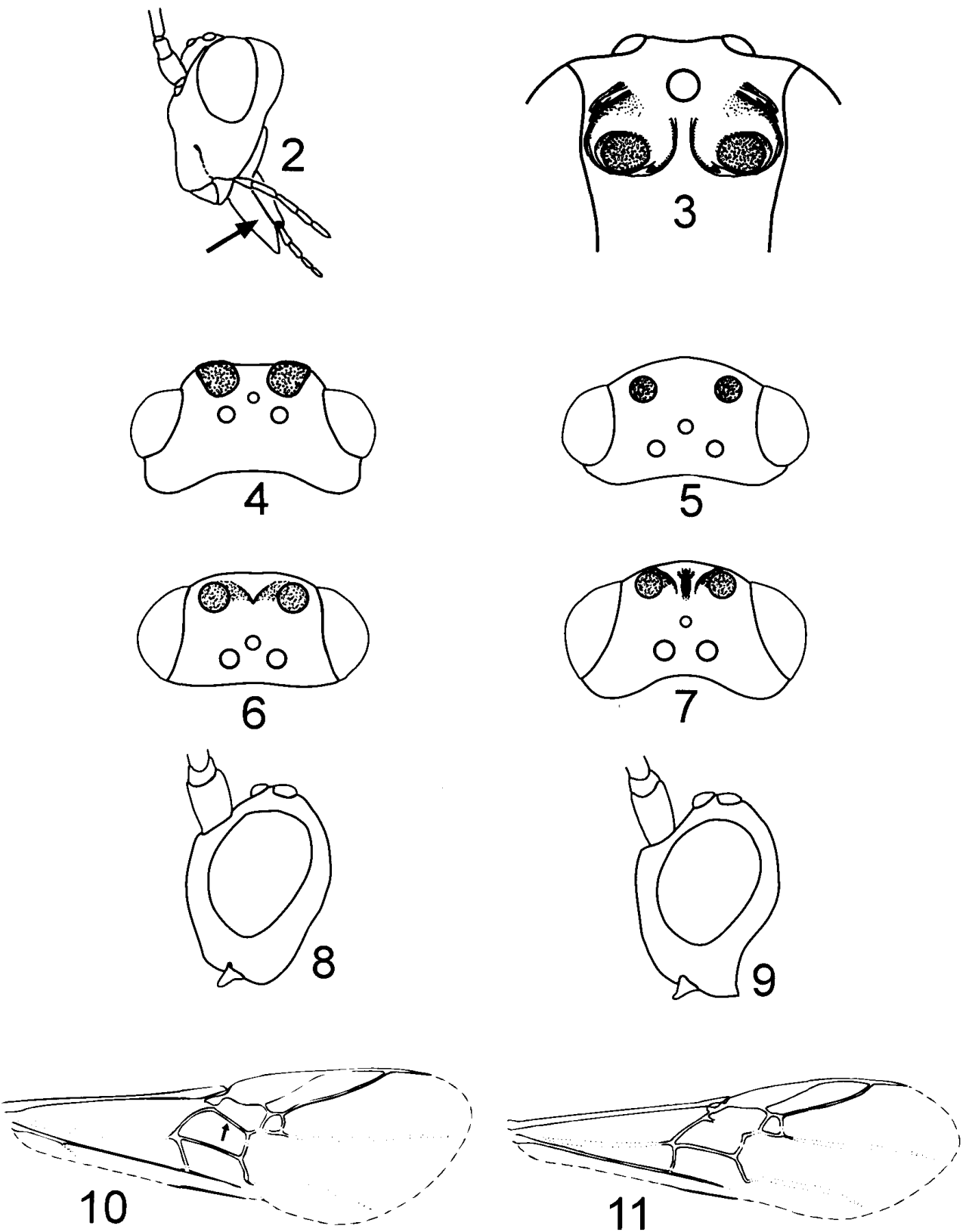

Figs 2-11. Morphology of agathidine wasps. 2, lateral view of head of Agathis sp. (arrow =galea); 3, dorsal view of frons of Coccygidium species showing lateral carinae; 4 , dorsal view of head of Bassus sp. showing bulging temples; 5-7, dorsal view of head of Bassus spp.; 8, lateral view of head of Bassus sp. showing rounded gena; 9, lateral view of head of Bassus sp. showing acute gena; 10, right forewing of Earinus sp. (arrow=vein RS $+\mathrm{M}$ ); 11, right forewing of Cremnops sp. 

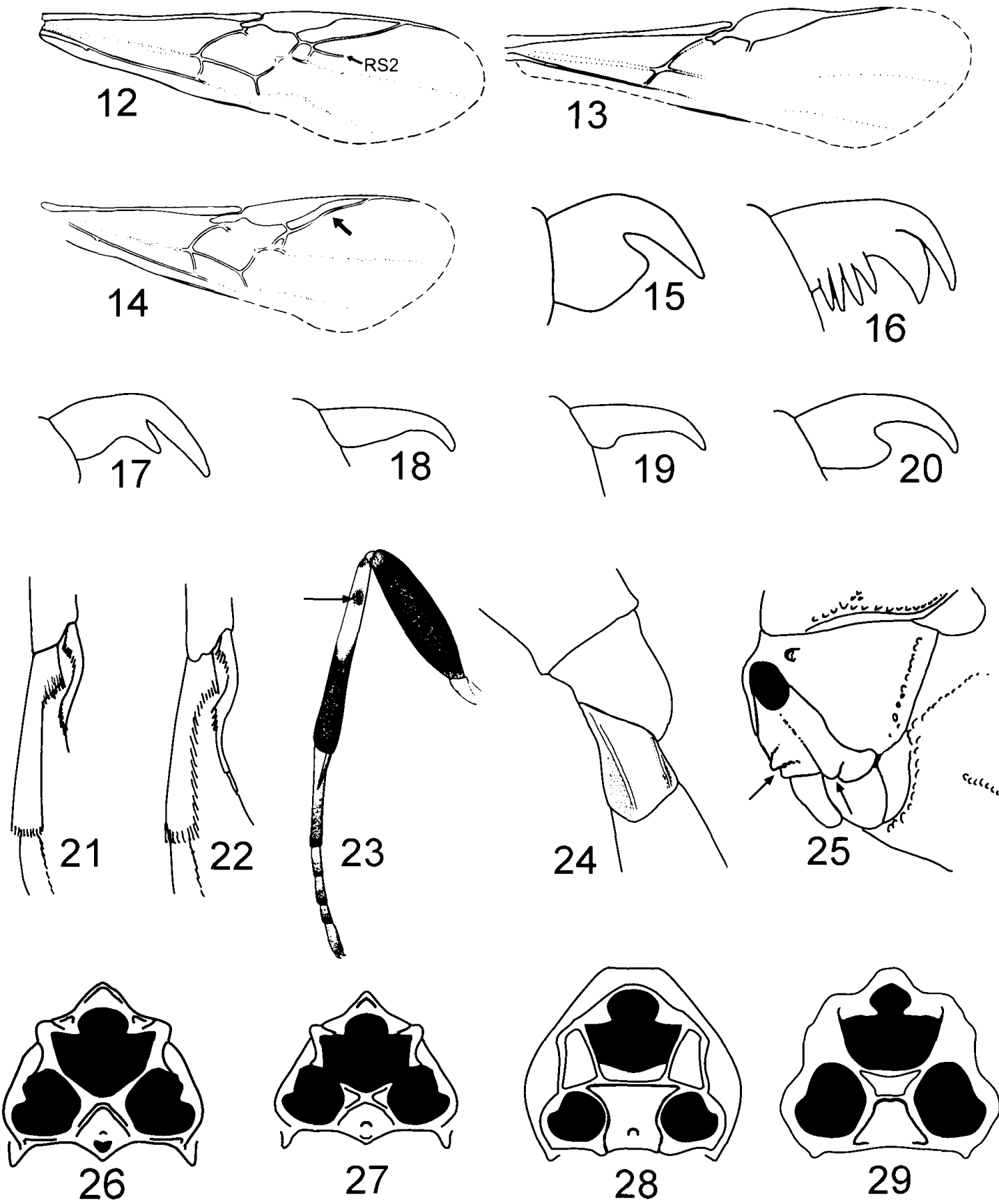

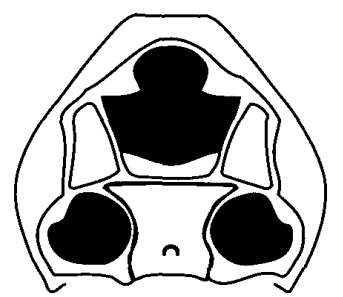

28

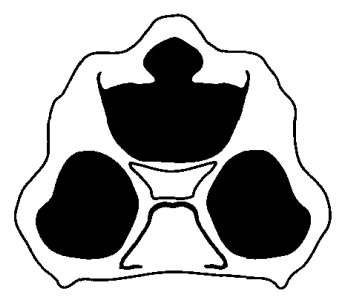

29

Figs 12-29. Morphology of agathidine wasps (continued). 12, right forewing of Braunsia postfurcalis; 13, right forewing of Aneurobracon philippinensis; 14, right forewing of Bassus coriarius; 15, foretarsal claw of Bassus sp.; 16, foretarsal claw of Cremnops sp.; 17, foretarsal claw of Coccygidium sp.; 18-20, foretarsal claw of Agathis spp.; 21, basal tarsomere of foreleg of Coccygidium sp. showing relatively short tibial spur; 22, basal tarsomere of foreleg of Coccygidium sp. showing relatively long tibial spur; 23, hind leg of Bassus festivus showing basal spot (or band) of tibia (arrow); 24, ventral view of hind trochantellus of Coccygidium sp. showing two longitudinal ridges; 25, anterior view of mesosoma of Bassus sp. with head removed, showing large projections (bumps) on propleura (arrows); 26-27, posterior view of mesosoma of Agathis spp. with metasoma and hind legs removed; 28-29, posterior view of mesosoma of Bassus spp. with metasoma and hind legs removed. 
6(5). Galea elongate, always longer than wide (Fig. 2); propleuron flat or evenly convex, without distinct bump; coxal cavities not separated from metasomal foramen (Fig. 27), or separated by narrow sclerite (Fig. 26) ................ Agathis Galea not elongate, not longer than wide; propleuron usually $(85 \%)$ with distinct bump (Fig. 25); coxal cavities usually (85\%) separated from metasomal foramen by wide sclerite (Figs 28, 29) Bassus

7(1). Claws of fore and middle legs pectinate basally (Fig. 16); ovipositor at least as long as metasoma. Cremnops

- $\quad$ Claws of fore and middle legs not pectinate basally (Fig. 17); ovipositor shorter than metasoma 8

8(7). Hind trochantellus with one or two longitudinal carinae ventrally (Fig. 24); frons with (Fig. 3) or without lateral carinae. Coccygidium Hind trochantellus without longitudinal carina; frons without lateral carinae (Fig. 7). Euagathis

\section{Key to Russian Far East and Japanese Species of Agathis}

1. Hind femur partly or entirely melanic (at least basally) ............................. 2

- $\quad$ Hind femur entirely pale (yellow to light brown)........................................ 11

2(1). Hind femur entirely black; sternaulus absent. Japan (Honshu) Agathis asternaulus Sharkey, 1996

- $\quad$ Hind femur variable; sternaulus present at least posteriorly ........................ 3

3(2). Hind femur yellow except for extreme basal patch of melanic color .............. 4

- Hind femur with more melanic color ............................................................. 5

4(3). Galea about as long as head. Russia (Amur Oblast, Primorskiy Kray) ............. Agathis medinai Sharkey, 1998 Galea distinctly shorter than head. Widespread from Europe to the Russian Far East.... Agathis griseifrons Thompson, 1895

5(3). Hind femur black basally, yellowish brown distally; gena and mouthparts not elongate; galea about as long as wide. Widespread over the temperate Holarctic, introduced and established in North America.

Agathis pumila Ratzeburg, 1844 Hind femur variable; gena and mouthparts elongate; galea distinctly longer than wide

6(5). Basal lobe of foretarsal claws large, at least as large as in Fig. 20 ................ 7

- $\quad$ Basal lobe of foretarsal claws small (Fig. 19) or absent (Fig. 18) ...................... 9

7(6). Median tergite 2 striate. Japan (Hokkaido) .... Agathis kumatai Sharkey, 1996

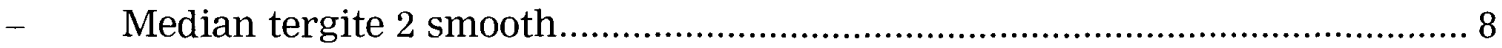

8(7). Galea length approximately equal to eye height. Distribution listed below Agathis cama Sharkey, 1998

- $\quad$ Galea length about 1.4 times eye height. Distribution listed below Agathis nigra Nees von Esenbeck, 1814

9(6). Mouthparts (excluding palpi) longer than head height. Russia (Primorskiy Kray) [According to Telenga (1955), Kemerovo Region, Krasnoyarsk Territory, Irkutsk Region, Nerchinsk, Yakutsk]........ Agathis genalis Telenga, 1955 Mouthparts (excluding palpi) shorter than head height............................... 10

10(9). Ovipositor length approximately equal to metasoma length. Distribution 
listed below

Agathis rostrata Tobias, 1963 Ovipositor length approximately equal to body length. Distribution listed below. Agathis semiaciculata Ivanov, 1899

11(1). Basal lobe of foretarsal claws small (Fig. 19) or absent (Fig. 18) ...................... 12

- Basal lobe of foretarsal claws large (Figs 15, 20) ........................................... 14

12(11). Body length greater than $4 \mathrm{~mm}$. Widespread in the Palearctic from Europe to the Russian Far East.... Agathis griseifrons Body length about $3 \mathrm{~mm}$ 13

13(12). Basal black band or spot of hind tibia present (Fig. 23). Russia (Primorskiy Kray); Japan (Honshu, Kyushu) Agathis maetoi Sharkey, 1996

- Basal black band or spot of hind tibia absent. Russia (Primorskiy Kray); Kazakhstan.... Agathis zaisanica Tobias, 1963

14(11). Hypopygium of females long, extending past tip of metasoma and notched apically; propodeum completely rugose. Distribution listed below

Agathis watanabei Sharkey, 1996

- Hypopygium of females not long, not extending past tip of metasoma and not notched apically; propodeum with large smooth areas mediolaterally. Russia (Amur Oblast, Primorskiy Kray).... Agathis medinai

\section{Key to Russian Far East and Japanese Species of Bassus}

1. Gena forming acute or 90-degree angle posteroventrally (Fig. 9); temple bulging as viewed dorsally (Fig. 4) ............................................................ 2

- Gena rounded posteroventrally (Fig. 8); temple usually not bulging as viewed dorsally (Figs 5-7) .......................................................................... 3

2(1). Hind coxa black; hind femur black. Russia (Primorskiy Kray); Japan (Honshu, Kyushu) ............................................. Bassus semistriatus (Walker, 1874)

- Hind coxa yellowish brown; hind femur yellowish brown. Russia (Primorskiy Kray, Chitinsk Oblast); Japan (Hokkaido, Honshu).

Bassus inopinatae (Tobias, 1976)

3(1). Basal lobe of tarsal claws absent (Fig. 18) .................................................... 4

- $\quad$ Basal lobe of tarsal claws present (Figs 15, 19, 20) ...................................... 5

4(3). Mesoscutum orange. Taiwan; Japan (Ryukyu Islands).

Bassus albifaciatus (Watanabe, 1934)

Mesoscutum black. Distribution listed below

Bassus ussuriensis (Telenga, 1933)

5(3). Sculpture on median line of frons between antennae coriaceous. Japan (Honshu) ...................................................... Bassus coriarius Sharkey, 1996

- $\quad$ Sculpture on median line of frons between antennae not coriaceous ............. 6

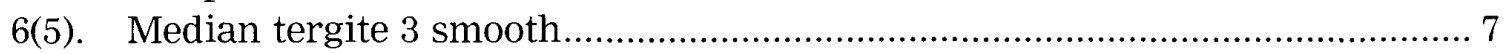

- $\quad$ Median tergite 3 striate, striogranulate, or coriaceous (granulate) ............... 15

7(6). Hind coxa yellowish brown medially, partly black laterally. Distribution listed below

Bassus conspicuus (Wesmael, 1837)

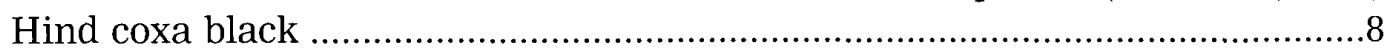

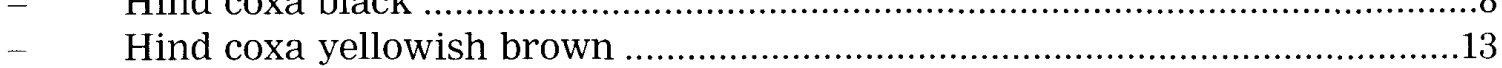

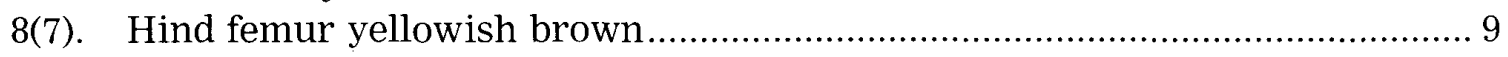

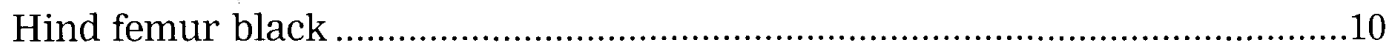


9(8). Hind tibia mostly melanic and with less than 10 apical spines; orbits of eye concolorous with temple and frons. Distribution listed below

Bassus belokobylskiji Sharkey, 1998

- Hind tibia mostly pale with more than 10 apical spines; orbits of eye paler (in part) than temple or frons. Distribution listed below ....

Bassus tobiasi Sharkey, 1998

10(8). Flagellomeres usually yellowish brown, much paler than head; if black, then sculpture of second metasomal median tergite completely striate to posterior margin. Russia (Primorskiy Kray); China; Taiwan; India; introduced to the USA. Bassus festivus (Muesebeck, 1953) Flagellomeres melanic and metasomal median tergite partly or entirely smooth.

11(10). Last abscissa of RS vein of forewing sinuate (cf. Fig. 14). Distribution listed below. Bassus cingulipes (Nees von Esenbeck, 1814)

- Last abscissa of RS vein of forewing straight or weakly curved..... 12

12(11). Hind tibia entirely black, without basal black band or spot; spines on lateral surface of foretibia present. Japan (Hokkaido)

Bassus spinosus Sharkey, 1996

- Hind tibia yellowish brown or otherwise pale in basal half or more, and with basal black band or spot; spines of foretibia absent. Distribution listed below

Bassus festivoides Sharkey, 1996

13(7). Orbits of eye concolorous with temple and frons; ovipositor sheath wider than apex of hind tibia (including setae in measurements). Distribution listed below ................................................. Bassus peniculus Sharkey, 1996

- Orbits of eye, at least in part, paler than temple and/or frons; ovipositor sheath not as wide as apex of hind tibia (including setae) ........................... 14

14(13). Hind coxal cavity either open, without complete sclerite separating it from metasomal foramen (cf. Fig. 27), or, less often, with very narrow sclerite (cf. Fig. 26). Distribution listed below.... Bassus conspicuus

- Hind coxal cavity closed, with wide sclerite separating it from metasomal foramen (cf. Fig. 28). Distribution listed below

. Bassus tumidulus (Nees von Esenbeck, 1814)

15(6). Strong transverse carina of propodeal pseudosternite present (cf. Fig. 28); interantennal space raised to converge on single point anteromedially (cf. Fig. 6)

- Strong transverse carina of propodeal pseudosternite absent; interantennal space flat or with weak median groove separating two prominences (cf. Figs $4,5,7)$, not converging on single point anteromedially. 18

16(15). Bump of propleuron weak. Japan (Honshu).

Bassus striogranulatus Sharkey, 1996

- $\quad$ Bump of propleuron strong (cf. Fig. 25) ... 17

17(16). Hind tibia entirely black. Distribution listed below.

Bassus romani (Shestakov, 1940)

Hind tibia partly yellowish brown. Widely distributed in the Palearctic, from Sweden to Turkey in Europe, and east to Japan in Asia; introduced into Argentina and USA (established in New Jersey).

18(15). Less than $3 \mathrm{~mm}$ in length; antenna with less than 28 flagellomeres. Russia 
(Primorskiy Kray)

Bassus clausiellus Sharkey, 1998

- $\quad$ More than $4 \mathrm{~mm}$ in length; antenna with more than 30 flagellomeres .......... 19 19(18). Hind coxa entirely black; median ridge between antennae (connecting face and median ocellus) present; posterior surface of scutellum rugose. Distribution listed below. Bassus pilosus (Tobias, 1976)

- Hind coxa yellowish brown medially and partly black laterally; median ridge between antennae (connecting face and median ocellus) absent; posterior surface of scutellum smooth. Japan (Honshu)

Bassus gracilis Sharkey, 1996

\section{Key to Russian Far East and Japanese Species of Coccygidium}

1. Frons margined with carinae (Fig. 3); spur length of foretibia more than 0.9 times length of basitarsomere (Fig. 22). Japan (Honshu); Iran; Turkmenistan; Uzbekistan..... Coccygidium transcaspicum (Kokujev, 1902) Frons unmargined, without carinae (cf. Fig. 7); spur length of foretibia less than 0.8 times length of basitarsomere (Fig. 21).

2(1). Mesosoma entirely black. Japan (Honshu); South Korea Coccygidium ruidum Sharkey, 1996

Mesosoma yellow and black. Japan (Honshu, Shikoku) .... Coccygidium varipes (Achterberg and Maetô, 1990)

- Mesosoma yellow to testaceous.... 3

3(2). Hind femur pale. Russia (Primorskiy Kray); Japan (widespread from Hokkaido to Kyushu) Coccygidium nihonense Sharkey, 1996

- $\quad$ Hind femur melanic. Russia (Primorskiy Kray) Coccygidium nigricrum Sharkey, 1998

Remarks. See Chou and Sharkey (1989) and Sharkey (1996) for a discussion of the synonymy of Zelomorpha Ashmead, 1900 with Coccygidium.

\section{Agathidinae of Sakhalin and the Kuril Islands}

Agathis cama Sharkey, 1998

Agathis cama Sharkey, 1998: 523-524.

Distribution. Russia (Primorskiy Kray, Khabarovskiy Kray); Kuril Islands (Kunashir).

Agathis nigra (Nees von Esenbeck, 1814)

Distribution. Widespread in the Palearctic from Europe to Iran, Kazakhstan, and European Russia. Here it is noted for the first time in the Russian Far East from Sakhalin Island [new island records: $2{ }^{*}$, SK-01-DJB-040; 1 \%, SK-01-DJB-076].

Host. Gelechiidae: Isophrictis striatella (Denis and Schiffermüller, 1775) in Tanacetum vulgare Linnaeus.

Remarks. This species has been found in many countries in the western Palearctic (Simbolotti and Achterberg 1999) but has yet to be noted for the mainland portion of the Russian Far East. However its presence on Sakhalin Island suggests it may be or formerly has been more widespread across the Palearctic. 
Agathis rostrata Tobias, 1963

Distribution. Russia (Primorskiy Kray); Kazakhstan; Kuril Islands (Iturup [new island record: 1 ㅇ, IT-99-DJB-077B]).

Agathis semiaciculata Ivanov, 1899

Distribution. Bulgaria; Switzerland; Russia (Primorskiy Kray, Amur Oblast, Sakhalin); Mongolia; Kazakhstan; Turkmenistan; Georgia; Ukraine; Moldova; Japan (Hokkaido, Honshu, Kyushu); Kuril Islands (Kunashir [new island records: 1。, KU-96-BKU-091; 2ㅇ, KU-97-YMM-048; $1{ }^{\star}$, KU-98-DJB-140; $1{ }^{\star}$, KU-98-BKU-131], Iturup [new island record: 19, IT-99-DJB-088]).

Agathis watanabei Sharkey, 1996

Distribution. Russia (Primorskiy Kray, Sakhalin); Japan (Hokkaido, Honshu, Kyushu); Kuril Islands (Habomai group: Zelyionyi [new island record: 5 q, ZE-98DJB-129] and Polonskogo [new island record: 19, PO-98-DJB-133]).

Bassus belokobylskiji Sharkey, 1998

Bassus belokobylskiji Sharkey, 1998: 525-526.

Distribution. Russia (Sakhalin).

Bassus cingulipes (Nees von Esenbeck, 1814)

Distribution. Widespread throughout the Russian Far East (Primorskiy Kray, Khabarovskiy Kray, Amur Oblast, Sakhalin) and throughout the Palearctic from western Europe to Japan (widespread), Taiwan, the Kuril Islands (Paramushir, Kunashir [new island records: $1 \%$, KU-97-YMM-035; $1 q$, KU-97-NM-001; $2 q$, KU-98-BKU-131], Iturup [new island records: 10, IT-95-BKU-007; 29, IT-98-DJB-077; 1 , IT-99-BKU-074], Shikotan [new island records: $1 \%$, SH-98-BKU-088; $1 \%$, SH-98BKU-108], Urup [new island record: $2+10$, UR-00-DJB-082]).

Hosts (according to Nixon 1986). Gelechiidae: Caryocolum fraternellum Douglas, 1851. Coleophoridae: Coleophora frischella (Linnaeus, 1758).

\section{Bassus conspicuus (Wesmael, 1837)}

Distribution. Widespread across the Palearctic from western Europe to Russian Far East (Primorskiy Kray, Khabarovskiy Kray, Amur Oblast, Sakhalin), the southern Kuril Islands (Kunashir, Iturup [new island records: 1\%, IT-96-BKU-089; 10 , IT-99-DJB-100]), Japan (widespread), and Taiwan. Introduced into the eastern USA and established.

Hosts. Cochylidae: Phalonidia manniana (Fischer von Röslerstamm, 1839). Pyralidae: Dipleurina lacustrata (Panzer, 1804). Tortricidae: Cydia pomonella (Linnaeus, 1758), Gypnosoma nitidulana (Lienig and Zeller, 1846), Grapholita molesta (Busck, 1916), Pammene regiana (Zeller, 1849), and Rhopobota ustomaculana (Curtis, 1831).

Bassus festivoides Sharkey, 1996

Distribution. Russia (Sakhalin); Japan (Hokkaido, Honshu, Kyushu); Kuril Islands (Kunashir). 
Bassus peniculus Sharkey, 1996

Distribution. Russia (Primorskiy Kray, Sakhalin); Japan (Hokkaido).

Bassus pilosus (Tobias, 1976)

Distribution. Russia (Primorskiy Kray); Japan (Hokkaido, Honshu, Kyushu); Kuril Islands (Kunashir, Shikotan [new island record: 10, SH-98-DJB-085], Iturup [new island record: 1\%, IT-95-BKU-007]).

Bassus romani (Shestakov, 1940)

Microdus romani Shestakov, 1940: 14.

Agathis ebula Nixon, 1950: 469. [Synonymized by Sharkey 1998]

Bassus ater Chou and Sharkey, 1989: 155-156. [Synonymized by Sharkey 1998]

Distribution. Widespread over the East Palearctic, from India to Taiwan, East Siberia, Primorskiy Kray, Japan (widespread), the Kuril Islands (Kunashir [new island records: $1 \%$, KU-98-DJB-140; 10 , KU-98-BKU-131], Shikotan [new island records: $1 \delta^{\star}$, SH-98-BKU-088; 10 , SH-98-BKU-101; 1 ${ }^{\dagger}$, SH-98-BKU-103; 1 क 17 , SH-98-

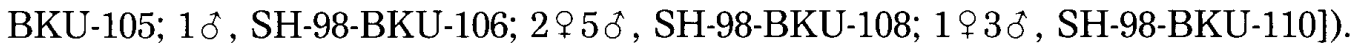

Host. Tortricidae: Acroclita notophthalma Meyrick, 1933.

Bassus tobiasi Sharkey, 1998

Bassus tobiasi Sharkey, 1998: 526-527.

Distribution. Russia (Primorskiy Kray, Amur Oblast, Sakhalin).

Bassus tumidulus (Nees von Esenbeck, 1814)

Distribution. Widespread in the Russian Far East (including Sakhalin and Moneron islands [new island record: 10, MO-01-DJB-083]) and the cool temperate areas of the Palearctic from western Europe to Japan (Hokkaido) and the Kuril Islands (Kunashir).

Hosts. Tortricidae: Cydia tenebrosana (Duponchel, 1843) on Rosa Linnaeus, Dichrorhampha acuminatana (Lienig and Zeller, 1846) on Chrysanthemum leudantemum Linnaeus, Epiblema scutellana (Denis and Schiffermüller, 1775) on Cirsium Miller, Epiblema cirsiana (Zeller, 1843) on Centaurea nigra Linnaeus, and Lathronympha strigata (Fabricius, 1775) on Hypericum Linnaeus.

\section{Bassus ussuriensis (Telenga, 1933)}

Distribution. Russia (Primorskiy Kray, Sakhalin [new island records: 1 , SK01-DJB-049; 3 , SK-01-DJB-077]); Japan (Hokkaido, Honshu, Shikoku, Kyushu).

Branusia antefurcalis Watanabe, 1937

Distribution. Russia (Primorskiy Kray, Khabarovskiy Kray); Kuril Islands (Kunashir); Japan (Hokkaido, Shikoku, Kyushu); Korea.

Earinus elator (Fabricius, 1804)

Distribution. Widespread in Japan and the entire temperate Palearctic including Sakhalin, Khabarovskiy Kray, and Primorskiy Kray.

Hosts. Noctuidae: Agrochola circellaris (Hufnagel, 1776), Agrochola lota (Clerck, 1759) on Salix caprea Linnaeus, and Atethmia centrago (Haworth, 1809). 
Earinus jezoensis Watanabe, 1937

Distribution. Russia (Primorskiy Kray, Sakhalin); Japan (Hokkaido, Honshu, Shikoku, Kyushu).

Host. Tortricidae: Zeiraphera rufimitrana truncata Oku, 1968.

Earinus longensis Sharkey, 1996

Distribution. Russia (Sakhalin); Japan (Hokkaido, Honshu, Kyushu); Kuril Islands (exact distribution here unknown but presumably one or more of the southern islands).

\section{Discussion}

There are presently 14 species of Agathidinae known from Sakhalin, 12 from the Kurils, and 19 from both regions. Most of these (12 of 19) have widespread distributions throughout Japan, the Russian Far East, or the Palearctic at large. Only Bassus belokobylskiji is putatively endemic to Sakhalin. In the Kuril Islands, species are largely restricted to the southern group of Islands (Kunashir, Shikotan, Iturup, Urup, Habomai group). Despite the devotion of multiple field seasons of survey effort by the International Kuril Island Project (IKIP) to collect solely in the central and northern Kuril Islands, and despite the use of methods amenable to the collection of parasitic Hymenoptera (i.e. Malaise traps and sweep netting), only a single specimen (Agathis sp., KH-00-DJB-029) of the Agathidinae was taken outside the southern portion of the chain. This is in sharp contrast to the nearly 100 specimens of Agathis and Bassus taken from the southern islands during the project. However, this specimen, from the island of Kharimkotan, along with the occurrence of the widespread species Bassus cingulipes on Paramushir (Sharkey 1996: literature record not verified by IKIP surveys), shows that the Agathidinae may be exceedingly rare in these areas but are not entirely absent. Additional survey effort is needed in these poorly known areas to reveal their complete ranges, dispersal paths, and affinities to nearby land masses.

\section{Acknowledgements}

Support to MJS was provided by the Kentucky Agriculture Experiment Station Project, number 02-08-100. Biodiversity studies in the Russian Far East were supported in part by the Biological Sciences Directorate (Biotic Surveys and Inventories Program) and the International Program Division of the U.S. National Science Foundation, grant numbers DEB-9400821, DEB-9505031, and DEB-0071655, Theodore W. Pietsch, principal investigator. Thanks to Arkady Lelej of the Laboratory of Entomology, Institute of Biology and Pedology, Vladivostok, Russia, for translation help and for exceptional logistical support throughout the IKIP and ISIP surveys; Yuri Marusik for making specimens available; Noboru Minakawa, Brian Urbain, and Trevor Anderson for help in collecting specimens; and to Michael Engel for reviewing the manuscript. 


\section{Appendix: Locality Data for New Island Records}

IT-95-BKU-007: Iturup Is., $45^{\circ} 16.34^{\prime} \mathrm{N}, 147^{\circ} 52.39^{\prime} \mathrm{E}$, B. K. Urbain col., 3 Aug. 1995.

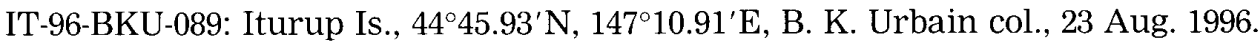

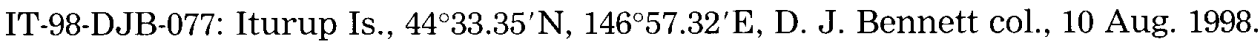

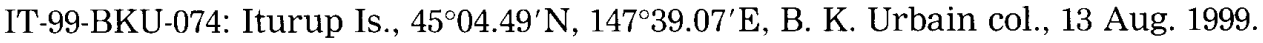
IT-99-DJB-077B: Iturup Is., 45²0.04' N, 14759.84' E, D. J. Bennett col., 14 Aug. 1999. IT-99-DJB-088: Iturup Is., 4505.12' N, 147 40.26' E, D. J. Bennett col., 13 Aug. 1999. IT-99-DJB-100: Iturup Is., $44^{\circ} 43.47^{\prime} \mathrm{N}, 147^{\circ} 12.43^{\prime} \mathrm{E}$, D. J. Bennett col., 13 Aug. 1999. KH-00-DJB-029: Kharimkotan Is., $49^{\circ} 08.75^{\prime} \mathrm{N}, 154^{\circ} 27.64^{\prime} \mathrm{E}$, D. J. Bennet col., 28 July 2000.

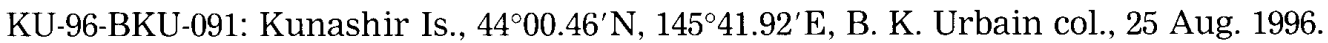

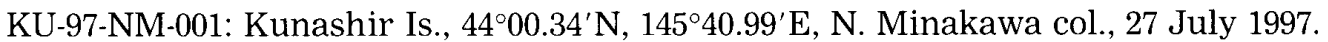
KU-97-YMM-035: Kunashir Is., Yuzhno-Kuril'sk environs, Y. Marusik col., Sept. 1997 (nonIKIP).

KU-97-YMM-048: Kunashir Is., SW shore, Cape Krugly, Y. Marusik col., Sept. 1997. KU-98-BKU-131: Kunashir Is., $44^{\circ} 03.07^{\prime}$ N, $145^{\circ} 49.25^{\prime}$ E, B. K. Urbain col., 22 Aug. 1998. KU-98-DJB-140: Kunashir Is., 440․ $035^{\prime} \mathrm{N}, 145^{\circ} 49.14^{\prime} \mathrm{E}$, D. J. Bennett col., 22 Aug. 1998. MO-01-DJB-083: Far East Russia, Moneron Is., $46^{\circ} 14.72^{\prime} \mathrm{N}, 141^{\circ} 14.00^{\prime} \mathrm{E}$, D. J. Bennett col., 24 Aug. 2001.

PO-98-DJB-133: Polonskogo Is. (Habomai group), $43^{\circ} 38.38^{\prime} \mathrm{N}, 146^{\circ} 18.56^{\prime} \mathrm{E}$, D. J. Bennett col., 24 Aug. 1998.

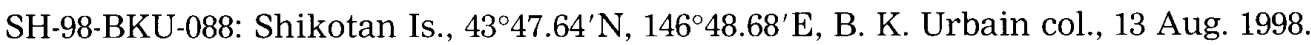

SH-98-BKU-101: Shikotan Is., $43^{\circ} 49.33^{\prime} \mathrm{N}, 146^{\circ} 42.67^{\prime} \mathrm{E}$, B. K. Urbain and E. M. Sayenko col., 18 Aug. 1998.

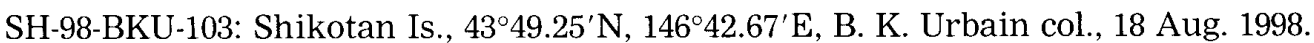

SH-98-BKU-105 and SH-98-BKU-106: Shikotan Is., $43^{\circ} 49.27^{\prime} \mathrm{N}, 146^{\circ} 42.57^{\prime} \mathrm{E}, \mathrm{B}$. K. Urbain col., 18 Aug. 1998.

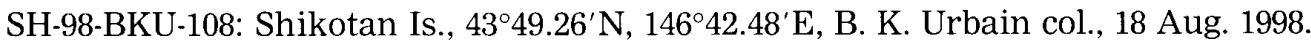

SH-98-BKU-110: Shikotan Is., $43^{\circ} 49.27^{\prime}$ N, $146^{\circ} 42.25^{\prime}$ E, B. K. Urbain col., 18 Aug. 1998.

SH-98-DJB-085: Shikotan Is., $43^{\circ} 52.25^{\prime} \mathrm{N}, 146^{\circ} 47.81^{\prime} \mathrm{E}$, D. J. Bennett col., 12 Aug. 1998.

SK-01-DJB-040: central Sakhalin, 5056.10'N, $142^{\circ} 45.57^{\prime}$ E, D. J. Bennett col., 6 Aug. 2001.

SK-01-DJB-049: southern Sakhalin, $47^{\circ} 15.08^{\prime} \mathrm{N}, 142^{\circ} 48.10^{\prime} \mathrm{E}$, D. J. Bennett and T. Anderson col., 31 July 2001.

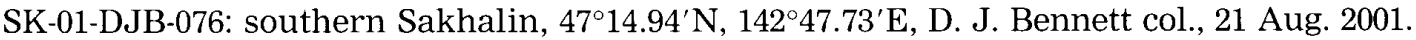

SK-01-DJB-077: southern Sakhalin, $47^{\circ} 15.08^{\prime} \mathrm{N}, 142^{\circ} 48.10^{\prime}$ E, D. J. Bennett and T. Anderson col., 12 Aug. 2001.

UR-00-DJB-082: Urup Is., $45^{\circ} 40.10^{\prime} \mathrm{N}, 149^{\circ} 28.64^{\prime} \mathrm{E}$, D. J. Bennett col., 8 Aug. 2000.

ZE-98-DJB-129: Zelionyi Is. (Habomai group), $43^{\circ} 29.29^{\prime} \mathrm{N}, 146^{\circ} 06.39^{\prime} \mathrm{E}$, D. J. Bennett col., 20 Aug. 1998.

\section{References}

Belokobylskij, S. A. 1989. Revision of the Palaearctic species of the genus Braunsia Kriechbaumer (Hymenoptera, Braconidae, Agathidinae). Trudy Zoologicheskogo Instituta 188: 58-72. [In Russian]

Belokobylskij, S. A. 1993. Contribution to the taxonomy of Braconidae (Hymenoptera) of the Russian Far East. Russian Entomological Journal 2: 87-103. 
Chou, L. and Sharkey, M. J. 1989. The Braconidae (Hymenoptera) of Taiwan. Journal of Taiwan Museum 42: 147-223.

Dondale, C. D. 1954. Biology of Agathis laticinctus (Cress.) (Hymenoptera: Braconidae) a parasite of the eye-spotted bud moth, in Nova Scotia. The Canadian Entomologist 86: 40-44.

Fabricius, J. C. 1804. Systema Piezatorum Secundum Ordines, Genera, Species Adiectis Synonymis, Locis, Observationibus, Descriptionibus. Reichard, Brunsvigae, $30+440$ pp.

Ivanov, P. 1899. Braconides cryptogastres et aréolaires des environs de Koupiansk, avec tableaux synoptiques des genres et des espèces de ces insectes. Trudy Obshchestva Ispytateleî Prirody pri Imperatorskom Khar'kovskom Universitete 33: 273-382.

Nees von Esenbeck, G. G. 1814 (1812). Ichneumonides adsciti in genera et familias divisi. Magazin der Gesellschaft Naturforschender Freunde zu Berlin 6: 183-221.

Nickels, C. B., Pierce, W. C. and Pinkney, C. C. 1950. Parasites of the pecan nut casebearer in Texas. Technical Bulletin of the Texas Department of Agriculture (1011): 1-21.

Nixon, G. E. J. 1950. New Indian Braconidae bred from lepidopterous defoliators (Hymenoptera). Annals and Magazine of Natural History (12) 3: 453-474.

Nixon, G. E. J. 1986. A revision of the European Agathidinae (Hymenoptera: Braconidae). Bulletin of the British Museum (Natural History), Entomology 52: 183-242.

Odebiyi, J. A. and Oatman, E. R. 1972. Biology of Agathis gibbosa (Hymenoptera: Braconidae), a primary parasite of the potato tuberworm. Annals of the Entomological Society of America 65: 1104-1114.

Odebiyi, J. A. and Oatman, E. R. 1977. Biology of Agathis unicolor (Schrottky) and Agathis gibbosa (Say) (Hymenoptera: Braconidae), primary parasites of the potato tuberworm. Hilgardia 45: 123-151.

Sharkey, M. J. 1996. The Agathidinae (Hymenoptera: Braconidae) of Japan. Bulletin of the National Institute of Agro-Environmental Sciences 13: 1-100.

Sharkey, M. J. 1998. [22. Subfamily Agathidinae]. Pp. 520-531. In: Lelej, A. S., Kupianskaya, A. N., Nemkov, P. G. and Kholin, S. K. (Eds) Keys to the Insects of Russian Far East, Vol. 4. Neuropteroidea, Mecoptera, Hymenoptera. Part 3. Dal'nauka, Vladivostok. [In Russian]

Sharkey, M. J. and Wharton, R. A. 1997. Morphology and terminology. Pp. 19-37. In: Wharton, R. A., Marsh, P. M. and Sharkey, M. J. (Eds) Manual of the New World Genera of the Family Braconidae (Hymenoptera). International Society of Hymenopterists, Washington, D.C.

Shestakov, A. 1940. Zur Kenntnis der Braconiden Ostsibiriens. Arkiv för Zoologi 32A (19): $1-21$.

Simbolotti, G. and Achterberg, C. van. 1999. Revision of the West Palaearctic species of the genus Agathis Latreille (Hymenoptera: Braconidae: Agathidinae). Zoologische Verhandelingen 325: 1-167.

Telenga, N. A. 1933. Einige neue Agathididae-Arten aus U.S.S.R. (Braconidae: Hymenoptera). Konowia 12: 245-247.

Telenga, N. A. 1955. [Hymenoptera. Vol. 5, No. 4. Family Braconidae: subfamily Microgasterinae, subfamily Agathidinae]. Fauna SSSR (n. s.) 61: 1-312. [In Russian]

Tobias, V. I. 1963. The species of the genus Agathis Latr. (Hymenoptera, Braconidae) from Kazakhstan and middle Asia. Entomologicheskoe Obozrenie 42: 864 883. [In Russian]

Tobias, V. I. 1976. [On the study of Far Eastern Braconidae of the genus Microdus Nees (Hymenoptera)]. Trudy Biologo-Pochvennogo Instituta 43 (146): 96-106. [In Russian]

Watanabe, C. 1937. A contribution to the knowledge of the Braconid fauna of the Empire of Japan. Journal of the Faculty of Agriculture, Hokkaido Imperial University 42: 1-188.

Wesmael, C. 1837. Monographie des Braconides de Belgique. Nouveaux Mémoires de l'Académie Royale des Sciences et Belles-Lettres de Bruxelles 10: 5-68. 